\title{
The Importance of "Contextualisation" in Small and Medium-Sized Firms Valuation: Evidences from an Italian Case Study
}

\author{
Damiano Montani ${ }^{1}$, Francesco Perrini ${ }^{2}$, Daniele Gervasio ${ }^{1} \&$ Andrea Pulcini ${ }^{1}$ \\ ${ }^{1}$ University of Bergamo, Bergamo, Italy \\ ${ }^{2}$ Bocconi University, Milano, Italy \\ Correspondence: Damiano Montani, University of Bergamo, Bergamo, Italy. E-mail: damiano.montani@unibg.it
}

Received: November 18, 2017

Accepted: December 8, 2017 Online Published: December 20, 2017

doi:10.5539/ijbm.v13n1p70

URL: https://doi.org/10.5539/ijbm.v13n1p70

\begin{abstract}
The valuation of a small or medium-sized enterprise through subjective methods, may not exclude a correct contextualisation of the data forming the information base of the estimate. "Contextualisation" refers to the general overview of all those elements that allow a proper definition of the enterprise's background. All of this serves in the analysis for the correct data necessary for the determination of values such as the economic and financial flows to discount, the timeframe of analysis and the discount rate. Without a correct contextualisation, it is not possible to reach a correct measurement of the company value in accordance with the studies on the "theory of value". After observing that "contextualisation" has not been widely studied till now for the theory of value, the present work analyses the incidence on the measurement of the company value, showing with an empirical case the different results that may be reached on the basis of the contextualisation of data. Hence, a correct "contextualisation" is crucial for the proper valuation of a company. Academic researches should take more carefully into consideration, this aspect concerning the valuation of a company and in particular, define more accurately the implementing rules in the assessment methods.
\end{abstract}

Keywords: business valuation, contextualisation, small-medium enterprises, theory of value

\section{Introduction}

The objective of the present work is to identify some issues affecting the correct assessment of a small and medium-sized company, with particular reference to those operating in Italy and the inter-related methods to assess their value.

As explained below, small and medium-sized businesses need specific methods to be assessed, since it is not possible to make direct reference to the market quotations of the corporate bonds. Nevertheless, these particular methods are not always applicable on an objective basis and in some cases, may give misleading results.

This happens for example, with this case study where, as will be shown, two different evaluation procedures that are formally correct lead to thoroughly divergent results. This is because the valuation is not addressed by an appropriate technical discipline (in this specific case, concerning the "contextualisation" of data in the environment in which the company operates).

The importance of this subject is directly related to the importance of small and medium-sized companies in the global economy. In fact, according to the data collected in the Member countries of the Organisation for Economic Co-operation and Development (OECD), small and medium-sized businesses operating in non-financial sectors reached $99.7 \%$ of total businesses in 2013 . Hence contributing for $60 \%$ of the overall employment and generating between $50 \%$ and $60 \%$ of the total added value (OECD, 2017).

What has been said about the importance of small and medium-sized enterprises is even more true for a country like Italy, where they played and continue to play, a key role in history and in the economic future of the country (Goodman, Bamford, \& Saynor, 2016). This is proved by the data collected by ISTAT (i.e. the Italian National Institute of Statistics): in 2013, Italian small and medium-sized businesses (Note 1) operating in the industrial and service sectors represented $99.92 \%$ of the total, providing work to $80.33 \%$ of the employed population and generating $69 \%$ of the added value of the overall production (ISTAT, 2015).

Therefore, taking into consideration the spread of small and medium-sized enterprises in Italy and elsewhere, it 
is manifest to understand the importance of adopting the correct methodologies to measure their value.

Included in the more general field of the theory of value, studies on business valuation have developed different methods to measure the value of a company: capital approach, income approach, financial approach, mixed approach, market approach, "dynamic approach" (for instance the Economic Value Added - EVA ${ }^{\circledR}$ - method). As a general rule, an approach based on flows is used to measure the economic value of equity of small entities in rare cases a market approach is chosen. This is because small and medium-sized businesses have distinctive characteristics and are small. Subsequently the use of data deriving from listed large-scale companies would lead to inconclusive results.

In order to accurately assess firm values, experts focused on the development of more and more complex formulae to assess the company's value. Particular care has been taken on determining the correct discount rates. Also guides as renowned as the International Valuation Standards (IVS), carried out by the International Valuation Standard Council (IVSC, 2017) and as for Italy, Principi Italiani di Valutazione (PIV), carried out by the so-called Organismo Italiano di Valutazione (OIV, 2015) focused their attention principally on the above-mentioned elements.

To date, in the field of company valuation, little significance has been attributed to "contextualisation". This term may be defined as the overall framework of all those elements that are necessary to properly describe and settle the company's background, in order to better define and pick out the fundamental data, as the basis for a correct assessment procedure.

If contextualisation procedures are misleading, the consequent value assessment can only be wrong, as it was established on an erroneous basis.

This work proposes a contribution to literature in this field, particularly for SMEs, through in depth investigation and examination of this subject.

In the context of the "theory of value", through the analysis of an empirical case taken from the Italian situation, we will show how a different "contextualisation" may take to entirely different results.

Considering that the results of a company valuation are deeply influenced by the data underlying the calculation of the chosen model (Penman, 2016), it is manifest that a different perspective of observation of the same business phenomenon (and, therefore a different contextualisation) may lead to select different data flows, expressing a very different final value of the company. It is concluded that an accurate contextualisation is the key element to valuate a company in the appropriate way.

\section{Theory of Value and Management of Company Value: Literature Review}

Early studies on value theory date back to the $17^{\text {th }}$ century and were carried out by a pool of economists, focusing the value of trade goods.

Many theories were developed over time - early in the field of "economics" - by Petty (1662), Chantillon (1775), Smith (1776), Ricardo (1817), and Torrens (1815), and then re-elaborated and examined in depth by other famous economists such as Malthus (1823), Marx and Engels (1867), Jevons (1871), Menger (1871), Marshall (1890), Walras (1900), Keynes (1936) and Sraffa (1960).

However, in a more recent view, studies on value and value creation have been developed as an academic discipline regarding "business economics" as well. The value creation is indeed a crucial goal for firms, their true raison d'être (Guatri, 1991).

The traditional approach aligned the value creation only with the maximisation of profits for the shareholders (Charreaux \& Desbrières, 2001) and thus, there was only a shareholder theory (Friedman, 1970). Over time, this vision has changed. Due to the development of the "stakeholder theory", that influenced more and more the studies not only about business economics but incorporated many other disciplines such as health, law and political economy (Harrison \& Wicks, 2013).

Thanks to the "stakeholder theory", people understood that the well-being of a company is directly related to its ability in order to satisfy the expectations of all the stakeholders, i.e. all the subjects that carry any kind of interest to the company and are indispensable for it (Donna, 1999). Subsequently every stakeholder puts pressure on the company to create the maximum value. Consequently, the stakeholder theory is restricted by the same managers of the company, that are not able to pursue and maximise at the same moment the objectives of all the stakeholders, since the different needs of the latter are often contradictory (Jensen, 2001; Jensen, 2002).

From this point of view, the main goal for a company should not be a "maximisation" but an "optimisation" of results, notwithstanding some of the stakeholders may have a leading position with respect to the others. 
Generally, this position is taken by shareholders. "Optimisation of results", derives from on the one hand, shareholders providing for the risk capital and defying the uncertainty more than the others stakeholders. Conversely, on the other hand, no company can decrease the level of satisfaction of the other stakeholders because - in a less amount - they support the company's risks too.

As a consequence, the best solution for value creation should be a combination between stakeholder and shareholder theory, as in a new pragmatic approach combining these two visions (Fatemi, Fooladi, \& Tehranian, 2015). This view is confirmed by many recent studies concerning corporate governance: in present economic systems, the trend is to embed the shareholder value practices in corporate governance systems that are rationally oriented to the interest of the stakeholders as well as, reaching an advanced and modern form of "stakeholder value approach" (Bottenberg, Tuschke, \& Flickinger, 2017).

After a brief description of historical evolution of thinking behind the theory of value, essential in order to define the state of art of this topic, it is worth to add that control and management of company value are the most fundamental issues studied by academic literature (Guatri, 1991).

Regarding management of value, studies in the field of marketing and strategic management were focused on the identification of the ways in which the company may maintain and increase the value created. In particular, the attention was devoted to two aspects: the process of value creation and the value outcome determinations (Gummerus, 2013).

The studies on the process of value creation have three different branches (Gummerus, 2013). The first and the most traditional, explains how the process of value creation is completely absorbed inside the company. For instance, some authors thought that the true sources of value creation were the resources, the expertise and the ability of the company itself (Wernerfelt, 1984; Porter, 1985; Barney, 1991; Treacy \& Wiersema, 1993; Stabell \& Fjeldstad, 1998).

The second branch shifts the focus from within the company to the external environment. More specifically, the centre of the process of value creation is determined in the interaction between company and customer and moreover is a value co-creation (Ranjan \& Read, 2016). The customer has an active role with the company (Prahalad \& Ramaswamy, 2004) through the direct or indirect cooperation in one or more phases of production or consumption (Payne, Storbacka \& Frow, 2008; Payne, Storbacka, Frow, \& Knox, 2009; Hoyer, Chandy, Dorotic, Krafft, \& Singh, 2010; Roggeveen, Tsiros, \& Grewal, 2012).

The third branch finds the process of value creation in what the customers do in their "daily life" with the products/services sold by the company. This is customer value creation. It has been written that "When consumption is seen as a productive process, the consumers themselves perform the final and crucial activities in the value-creating process' (Wikstrom, 1996). Within the vision of the customer value creation, the point of interest is not exchange or service, but how services provided by the company are considered in the context, in the activities, in the practices and in the customer experience as well as the implications of this for companies (Heinonen et al., 2010).

These three approaches towards the value creation seem to coexist in practice. Therefore, the managers should consider three different points of view in their decision making (Gummerus, 2013).

The studies on values identify four categories of value outcome determination: value as means-ends, value as benefits/sacrifices, value as experience outcomes, value outcome as phenomenological (Gummerus, 2013).

In accordance with the mean-end theory, the first approach analyses the valuation of products by customers taking into consideration the means-end chain. In particular, Woodruff (1997) spoke of customer value hierarchy: the value desired by the customer is composed of preferences related to measurable dimensions - the attributes, attribute performances and consequences - connected to the objectives for that specific use. By adopting this vision, the value may be appreciated at different levels of abstraction: the product attributes at the lowest, the attribute performances at the medium and goals and purposes at the highest level. After understanding which outcomes are desirable and which are not, the customers are expected to adopt their behaviour accordingly in order to act rationally (Gummerus, 2013).

The second approach, value as benefits/sacrifices, considers the value as a judgment of benefit expressed by the customer. This judgment may be determined by the relationship between quality of the service (i.e. benefit) and the cost sustained to obtain it (sacrifice) (Brady et al., 2005). Benefits may include different qualitative dimensions (Patterson \& Spreng, 1997) but also relational (Ravald \& Gronroos, 1996): time to market, know-how and social benefits (Ulaga, 2003). Sacrifices may be both monetary and non-monetary (Woodall, 2003). 
In the third approach, value as experience outcomes, the value is intended as what the customer perceives after using the product. Some studies pointed out how human beings are always looking for feelings. In this way the value is described from an emotional/hedonistic point of view (Hirschman \& Holbrook, 1982). Whereas other studies identified the value both from a hedonistic and utilitarian point of view (Babin \& James, 1994; Batra \& Ahtola, 1990; Sweeney \& Soutar, 2001). In addition to the hedonistic and utilitarian value, other categories of values were proposed. For example, the social value (Sheth, Newman, \& Gross, 1991a; 1991b).

The fourth category, value outcomes as phenomenological, was analysed by the literature concerning the S-D logic. Based on previous works (Thompson, Locander, \& Pollio, 1989), the outcome determination is explained both as phenomenological and experiential, referring to sensations, thoughts, awaits, expectations and actions of the beneficiaries. In turn, a phenomenological experience is a dynamic process in which some events stand out and others are in the background. These events are those over which customers pay attention (Gummerus, 2013). The value is always uniquely and phenomenologically determined by the beneficiaries (Vargo \& Lusch 2008).

\section{Measurement Issues and Data Contextualisation in Business Valuation: Theoretical Framework}

As previously pointed out, in addition to the management of the value, its control is another crucial organisational aspect when creating the value of a company. This second sphere of application is extremely important: only a periodic measurement of the value created by the company allows it to quantify the effects inspired by the system of business decisions.

It has been written that a company creates value when increasing the dimension of its economic capital, meaning the value of the company in terms of investment (Guatri, 1991).

Experts can assess the economic capital of a company by choosing some different methods, particularly for small and medium sized companies (Lippitt \& Mastracchio, 1993).

In order to better understand the measurement issues, especially for SMEs, it may be useful to show a concise description of the main business evaluation methods.

The oldest methods, otherwise said "capital methods", were based on analytic valuation of current value of the single elements of assets and liabilities. A more complex concept within the "capital method" considers even intangible assets that are unaccounted in the balance sheet. Capital methods have significant methodological limits, since they estimate company value as an algebraic difference between adjusted assets and liabilities. Nevertheless, though the capital method is "static", for the assessment of current value of some assets (for instance intangibles), discounting forward-looking flows generated by these goods is suitable (Perrini, Chiaccheri \& Perrone, 2008). Nowadays, in practice, capital method is used mainly in particular assessments, characterised by capital prevalence (for example, holdings or real estate companies), or public undertakings, in particular for privatisation (Sichigea \& Berceanu, 2006), or when appreciation of future income flows is very difficult (Hromei \& Voinea, 2014).

As evolution of previous methods, "income approach" bases the company value on the ability to generate prospective income, through three logical steps: 1) set the timeframe for the flow analysis; 2) assess of "normal expected' income flows; 3 ) set of the correct discount rate.

As a diversification of previous methods, it is worth referring to the work carried out by the "Fédération Européenne des Experts Comptables Economiques et Financiers" (1961). It created the "mixed method", that is the union of capital method and income method. Actually, a similar method called "Excess Earning Method" has been used by the Department of Treasury of the United States since 1920 (West \& Jones, 1992).

An alternative way to determine the economic capital of a company is the financial model (Fernández, 2007a) that emphasizes the role of forward-looking cash flows (Burns \& Walker, 1991), estimating company value through a discount of cash flows expected from the investment and the discount of the potential residual value (Stewart, 1991). Generally, the cash flows can be levered or unlevered. The main problem in financial method implementation is the identification of Terminal Value (TV). In some contexts, TV may represent the greater part of total company value (Reis \& Augusto, 2013). Numerous studies have been carried out over time to analyse the terminal value and define the content and the measuring (Bernard, 1994; Kaplan \& Ruback, 1995; Bernard, 1995; Berkman, Bradbury, \& Ferguson, 1998; Penman, 1998; Penman \& Sougiannis, 1998; Francis, Olsson, \& Oswald, 2000; Courteau, Kao, \& Richardson., 2001; Courteau, Gray, Kao, O’Keefe, \& Richardson, 2007; Fernandez, 2007b; Cassia, Plate, \& Vismara, 2007; Jennergen, 2008; Pascual \& Jimenz, 2009; Reis \& Augusto, 2014; Cornell \& Gerger, 2017).

An alternative approach to determine the company value is based on market multiples and refers to comparable multiples or transactions in the stockmarket. This approach is widely used in the practice because it is very 
simple to apply. A selection of an actually comparable sample of businesses (or deals) is basis for a correct application of the method. Due to the lack of definite procedures, this method has been known as a 'form of art' for a long time (Golz, 1986; Woodcock, 1992; McCarthy, 1999). Untill Bhojraj \& Lee (2002) developed a systematic process to select comparable companies. Nevertheless, beyond the endeavor, this approach still has significant limitations (Damodaran, 2016). Moreover, the approach based on the market is not widely used to evaluate small and medium-sized businesses that notoriously may be unrelated to stock markets.

An alternative way to determine the economic capital of a company is the model based on economic indicator called "Economic Value Added ®" (EVA) (Ehrbar \& Stewart, 1999; Stern, Stewart, \& Chew, 1996). EVA ® is a business performance indicator which may be used as an actual management tool (Bahri, St-Pierre, \& Sakka, 2011): if EVA ${ }^{\circledR}$ has a positive value, it means that all the shareholders are paid accordingly for their investment; a negative EVA ${ }^{\circledR}$ means that the value has been destroyed (Young, 1997), i.e. the project had a lower income related to the cost of the capital (Lovata \& Costigan, 2002). To determine the value of a company, the Market Value Added (MVA) should be calculated and this represents the forward-looking annual EVA discount that the company expects to generate (Niresh \& Alfred, 2014). By adding the MVA to the Net Invested Capital (determined by adding net assets to net financial position expressed in book values), the total value of the company is determined.

In the light of the above, it is noticeable a broad uncertainty in the evaluation process due to different methods and above all, to a tricky procedure in data collecting.

In the methods above explained, company evaluation depends mainly on three elements: flows to discount, timeframe and discount rate; these data are the fundamental basis of a company value assessment. As a consequence, an inadequate data picking can be the most hazardous issue in business evaluation.

As for the identification of flows to discount and more in general of data that are at the basis of the estimate, one of the main aspects has not been analysed in depth till now: "contextualisation". This term refers to the general overview of all those elements that allow the proper definition of the company background.

Even the International Valuation Standards (IVS) deal broadly with similar topics: particularly, we mention the IVS 101 (paragraph 20.3, j), the IVS 102 (paragraph 20.2), and the IVS 200 (paragraph 80.) Note however, contextualisation is neither directly dealt with nor adequately considered. A similar lack can be found in Italian "Principi Italiani di Valutazione" (PIV) (Note 2), where the importance of contextualisation is not sufficiently considered.

Notwithstanding, we argue that contextualisation has a key role in company value assessment. As the below case study will point out, the choice of the "valuation perimeter" may dramatically affect the quality of assessment.

In such a situation, the effectiveness of Heisenberg's uncertainty principle may be confirmed in economic and corporate context. This principle was developed by the German physicist Werner Karl Heisenberg in 1927 and till now, it is considered as the cornerstone of the quantum theory (Gribbin, 1995). Heisenberg's uncertainty principle points out how the observation and/or the measurement influences the result observed/measured (Gribbin, 1984). It may be found not only in the quantum physics sector but even in economics, as suggested by a recent study (Ellwood \& Greenwood, 2016).

By extrapolating this principle into company valuation, a different overview of business may influence the business itself.

As a consequence, a different contextualisation of the same background may result in quite different outcomes, despite identical procedures.

\section{Method}

We will adopt a case study approach in order to demonstrate the importance of data contextualisation in company valuations, thereby building theoretical principles from the analysis of case studies in presence of the replicative logic (Eisenhardt, 1989; Yin, 1994). The analysis of case studies is considered as one of the best ways (if not the best one) to connect the richness of empirical qualitative evidences with deductive research (Eisenhard \& Graebner, 2007).

The empirical case deals with the valuation of an Italian medium-sized company, with the view to estimate the withdrawal value for a minority shareholder.

According to Italian law, the departing shareholder of a limited liability company must be refunded proportionally to company value at withdrawal time (Italian civil code, article 2473, paragraph 3).

In this paper we analyse two completely opposed documents: 
- the assessment drawn up by the withdrawing shareholder's expert;

- the assessment submitted by the official expert appointed by the court.

Although the empirical case is based on the analysis of two official assessments only, the evidences are very meaningful to highlight the issue. Indeed, thanks to the presence of a replicative logic, the findings can be considered universally valid.

\section{Case Study}

Alfa S.r.l. is a limited company with about 40 million Euros share capital; main assets are represented by real estate and trademarks to rent. The company has two shareholders: Beta S.p.a., bearing 13\% shares (minority shareholder) and Gamma S.p.a., bearing $87 \%$ shares (majority shareholder).

In February 2016 (date of evaluation), the minority partner Beta S.p.a. was enabled by law to withdraw, by asking the company for reimbursement of the value of his shares.

The withdrawing shareholder disagreed with the reimbursement amount proposed by the company and as a consequence, decided to sue the company at the court.

Therefore, two experts were entrusted with assessing the company's value: the former at the initiative of the court (official expert - from now on called "expert A") and the latter at the initiative of the complaining party (from now on called "expert B").

Both experts had the same task: estimate on the same day the company value (Alfa S.r.l.) and therefore, the withdrawing value owed to Beta S.p.a.

In order to give an overview of the events, it is important to highlight that Alfa S.r.l. is part of a manufacturing corporate group where:

- Gamma S.p.a. (majority shareholder of Alfa S.r.l.) performs the role of holding. Alfa S.r.l. is subjected to the management and coordination activity by Gamma S.p.a. (former article 2497 and following of the Civil Code);

- Delta S.p.a. (whose capital is totally owned by Gamma S.p.a.) is the "productive" company of the group. This company carries out manufacturing activities and sells the goods produced on the market. It is subject to the management and coordination activity by Gamma S.p.a. as well (former article 2497 of the Civil Code).

Figure 1 gives a better explanation of the structure of the group.

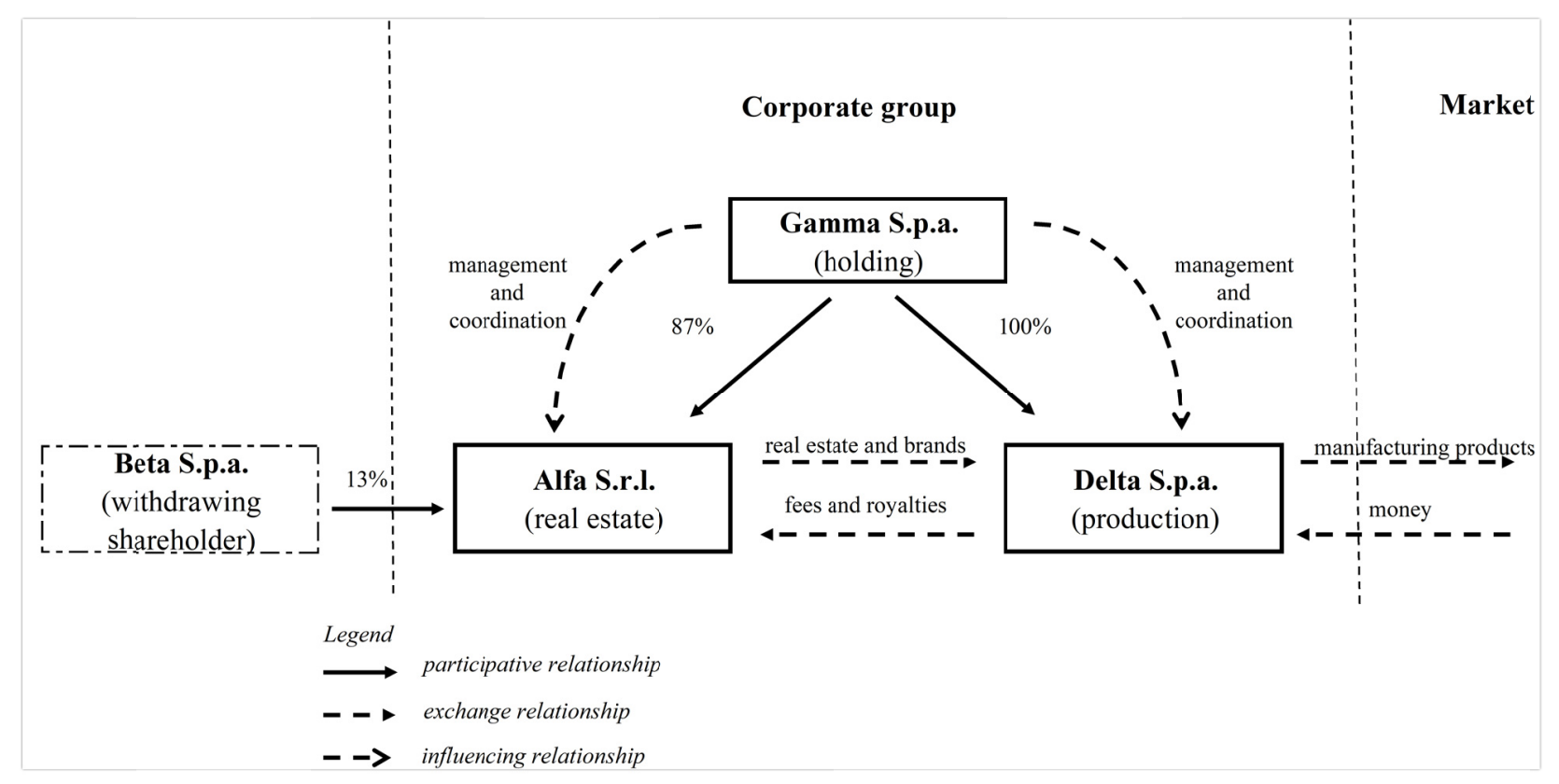

Figure 1. Corporate group structure

Alfa S.r.l. is a service company available for the group and its properties are mainly composed by the following assets: 
- fixed assets/real estate (industrial buildings), rented to the productive company belonging to the group (Delta S.p.a.);

- "brands", licensed to the productive company of the group (Delta S.p.a.). The latter pays royalties to Alfa S.r.l.

On the basis of these informations, two opposite experts carry out their assessment on company values.

Since Alfa S.r.l. is a service company, both experts choose the same valuation method: the capital approach according to the company value is determined through the re-expression to current values of business assets and liabilities.

Both experts assess different real estate values: 48 million Euros for the expert A and about 68 million Euros for the expert $\mathrm{B}$. These different results are due to current deep volatility in Italian real estate market.

However real estate is not the main issue of this case study. On the contrary, the main question is the assessment regarding the current value of the brands owned by Alfa S.r.l.

In order to assess the value of the brands, both experts decide to adopt the royalty rate method (RRM). The latter determines the brand value on the basis of the following formula:

where:

$$
W_{b}=\sum_{i=1}^{n} r S_{i} v^{i}
$$

$\mathrm{W}_{\mathrm{b}}=$ brand value;

$\mathrm{r}=$ royalty rate;

$\mathrm{S}_{\mathrm{i}}=$ sales expected over a timeframe corresponding to the residual life of the brand;

$\mathrm{v}^{\mathrm{i}}=$ discount rate.

The brand value estimate needs four elements: the royalty rate to apply, the size to which the royalty rate is to be applied, the timeframe of analysis and the discount rate.

As for the determination of the discount rate, both experts decide to adopt the Capital Asset Pricing Model (CAPM). Both experts define a quite similar discount rate:

$-6,29 \%$ discount rate for the expert A;

$-5,45 \%$ discount rate for the expert B.

The two experts reach very different values in the determination of the other elements for the estimate of the brand values.

In order to define the value of the flows to discount and the timeframe of analysis, the expert A based it on what is provided for in the license contracts of the brands signed between Alfa S.r.l. and Delta S.p.a. Thus, the timeframe used for the discount is equal to the duration of the contracts in question (5 years), except for a brand, for which the expert decided to adopt an unlimited timeframe. The flows to discount are determined by applying the royalty rates provided for by contracts on an average profit of the licensee (Delta S.p.a.). The expert A identified the licensee's average profit on which the royalty rates should be applied with an arithmetic mean that took into consideration both the historical records (years 2014-2015) and the forecasts of the business plan given by the management of Delta S.p.a. (years 2016, 2017, 2018). Of course, in order to determine the licensee's profits in the years 2014-2018, the expert A followed the provisions of the license contracts of brands (and thus starting from the revenues highlighted in the balance sheet, or by the business plan. The required amendments provided by the contracts were made - for example profit should be net of license charges etc.).

The expert A reached an average profit on which 1.57 million Euros contracts royalties are to be applied. By multiplying this value by the royalties provided for by license contracts of brands and discounting on the basis of the rate identified in the timeframe chosen, the expert A reached a value of brands of 4.8 million Euros.

The expert B makes very different choices, deciding not to base the valuation on what provided for by the license contracts of brands signed between Alfa S.r.l. and Delta S.p.a. This is because expert B thinks that Alfa S.r.l should be evaluated in the context of its corporate group. By adopting this viewpoint of the business, the expert B considers that the contracts signed between Alfa S.r.l. and Delta S.p.a are not useful to express a current value of brands because they were the result of the negotiations between two subsidiaries, under the auspices of a sole subject that exercises the management and coordination activity: Gamma S.p.a. As a holding, the latter does not operate in the interest of the single company (Alfa S.r.1.), but in the interest of the group. In view of this consideration, the expert B decides to adopt as a royalty rate $9 \%$ chosen after comparing similar cases on the market instead of what is provided for in the contracts. The flows to discount are determined by multiplying the 
royalty rate by the average revenue of Delta S.p.a. The latter is calculated as an arithmetic mean of 2014 and 2015 revenues (taken from the financial statements of Delta S.p.a.) and the prospective revenues of 2016, 2017 and 2018 (taken from the business plan made by the management of Delta S.p.a.). The average revenue identified by the expert B is about 46 million Euros. The average royalty flow to discount (calculated as the product of the average revenue and the royalty rate identified) is about 4.1 million Euros. As for the timeframe, the expert $\mathrm{B}$ does not take into consideration the duration of contracts. He considers the above mentioned brands as immovable items that are not subject to deterioration and with a great "strength" (Note 3.) Subsequently he opted for an undefined timeframe. According to the expert B the value of the brands is about 76 million Euros.

Table 1. Summarises the choices made by the experts in the valuation of the brands.

\begin{tabular}{|c|c|c|}
\hline & Expert A & Expert B \\
\hline Method of valuation of brands & royalty rate method & royalty rate method \\
\hline Royalty rate to apply & $\begin{array}{c}\text { Based on what is provided for in the } \\
\text { contracts signed between Alfa S.r.l. and } \\
\text { Delta S.p.a. [1] }\end{array}$ & Based on market analyses $(9 \%)$ \\
\hline $\begin{array}{l}\text { Flows on which the royalty rate is } \\
\text { to be applied }\end{array}$ & $\begin{array}{l}\text { Based on what is provided for in the } \\
\text { contracts signed between Alfa S.r.l. and } \\
\text { Delta S.p.a. (average profit flow emerging } \\
\text { from the application of contracts: } \\
1.570 .000 \text { euros) }\end{array}$ & $\begin{array}{l}\text { Average income of Delta S.p.a. (equal } \\
\text { to } 46.000 .000 \text { euros) }\end{array}$ \\
\hline Timeframe & $\begin{array}{c}\text { Equal to the duration of the license } \\
\text { contracts of brands signed between Alfa } \\
\text { S.r.l. and Delta S.p.a. [2] }\end{array}$ & Undefined \\
\hline $\begin{array}{l}\text { Final value of the brands } \\
\text { belonging to Alfa S.r.l. (euros) }\end{array}$ & 4.800 .000 & 76.000 .000 \\
\hline
\end{tabular}

Both experts estimate that the value of the other elements of the assets (credits and cash) of the company Alfa S.r.l. is around 3.3 million Euros. In view of the write-downs of real estates and brands made in 2015 by Alfa S.r.l., the expert B decides to take into consideration their valuation, the credits for prepaid taxes equal to 9 million Euros. Expert A however, considered that it was not possible to use the credits for prepaid activities and therefore did not include them in the assessment (Note 4).

Liabilities are estimated in the same way by the two experts, around 23 million Euros. In addition, the expert B took into consideration the potential fiscal charges related to the amendments carried out to the accounting items (in particular brands and real estate) to express them at the current values. The potential fiscal charge is about 22 million Euros. In the valuation report, the expert A does not take into consideration any fiscal elements. This occurred because the estimate reaches lower values with respect to the book value and the potential fiscal element would be represented by the credits for prepaid taxes. Nevertheless, as explained before, the expert A considers that Alfa S.r.l. may not benefit from any fiscal advantage in the near future.

The value of the economic capital of Alfa S.r.l. found by the expert A is about 33.1 million Euros. The value of the share due to the withdrawing shareholder Beta S.p.a. is about 4.3 million Euros.

The value of the economic capital of Alfa S.r.l. found by the expert B is about 111.3 million Euros. The value of the share due to the withdrawing shareholder Beta S.p.a. is about 14.5 million Euros.

\section{Results}

The abovementioned empirical case pointed out the ways in which the two experts carried out their task. Table 2 is useful to facilitate the analysis of the evidences emerging from the case study. 
As it may be seen on the penultimate row of the table 2, the two experts reach very different estimates of the economic capital of Alfa S.r.l. As a consequence, the value of the share of the withdrawing shareholder Beta S.p.a is different. The value emerging from the work made by the expert B is three times higher than the value of the expert A.

Considering that the business environment examined is the same as well as the model adopted (the capital approach), it is important to determine why the final values so different.

Table 2. Summary of Book values, Estimate values Expert A and Estimate values Expert B

\begin{tabular}{|c|c|c|c|}
\hline Asset and liabilities Alfa S.r.l. & $\begin{array}{l}\text { Book values } \\
\text { (Euros) }\end{array}$ & $\begin{array}{l}\text { Estimate values } \\
\text { Expert A (Euros) }\end{array}$ & $\begin{array}{l}\text { Estimate values } \\
\text { Expert B (Euros) }\end{array}$ \\
\hline Real estate & 57.500 .000 & 48.000 .000 & 68.000 .000 \\
\hline Brands & 3.000 .000 & $4.800 .000 \quad[1]$ & $76.000 .000 \quad[2]$ \\
\hline Other activities (credits and cash) & 3.300 .000 & 3.300 .000 & 3.300 .000 \\
\hline Credits for prepaid taxes & 0 & $0[3]$ & $9.000 .000 \quad[4]$ \\
\hline Total Assets & 63.800 .000 & 56.100 .000 & 156.300 .000 \\
\hline Liabilities (debts) & 23.000 .000 & 23.000 .000 & 23.000 .000 \\
\hline Equity capital & 40.800 .000 & 33.100 .000 & 133.300.000 \\
\hline $\begin{array}{r}\text { Potential fiscal charges deriving fro } \\
\text { amendment }\end{array}$ & al estate and brands & $0[5]$ & $22.000 .000[6]$ \\
\hline Modified equity capital (econom & pital of Alfa S.r.l.) & 33.100 .000 & 111.300 .000 \\
\hline $\begin{array}{r}\text { Share value of the withdrawing s } \\
\text { modified equity }\end{array}$ & $\begin{array}{l}\text { holder }(13 \% \text { of the } \\
\text { al) }\end{array}$ & 4.303.000 & 14.469 .000 \\
\hline \multicolumn{4}{|c|}{$\begin{array}{l}\text { [1] Valuation carried out with the royalty rate method. The instructions of the contracts signed between Alfa } \\
\text { S.r.l. and Delta S.p.a were followed. } \\
\text { [2] Valuation carried out with the royalty rate method. The instructions of the contracts signed between Alfa } \\
\text { S.r.l. and Delta S.p.a were not followed. }\end{array}$} \\
\hline \multicolumn{4}{|c|}{ [3] Expert A considers that it is not possible to use the credits for prepaid taxes } \\
\hline \multicolumn{4}{|c|}{ [4] Expert B considers that it is possible to use the credits for prepaid taxes } \\
\hline \multicolumn{4}{|c|}{ [5] Expert A considers that it is not possible to use the credits for prepaid taxes } \\
\hline
\end{tabular}

By analysing Table 2, the main different element is the brand valuation. For the assessment of these immovable items, both experts used the same method: the royalty rate method. Also, the discount rate was determined by both through the CAPM method, in fact the data obtained is very similar. The main difference is in the contextualisation carried out by the two - and this gives an answer to the question asked previously.

Expert A did not give a high relevance to the fact that Alfa S.r.l. operated in a corporate group. He considered Alfa S.r.l. as an independent normal company that is autonomously operating. Thus, to estimate the value of the brands, he based on the flows that Alfa S.r.l. receives from Delta S.p.a., that is the user of the brands. These flows are determined by the license contract of brands signed between Alfa S.r.l. and Delta S.p.a.

Expert B carried out the work by adopting a different viewpoint. He decided to valuate Alfa S.r.l. in the group context in which it operates. Starting from this assumption, the expert B decided not to stop on the content of the license contracts of the brands signed between Alfa S.r.l. and Delta S.p.a. From his viewpoint, these contracts do not allow to express the real market value of the brands, since the economic parameters contained are not the 
result of a "free market" negotiation among independent parties. They derive from a deal concluded between two subsidiaries that are subject to the management and coordination activity of a single company: Gamma S.p.a. The latter, as the majority shareholder, does not operate in the interest of the single company but in the interest of the group itself. In the opinion of expert B, the modification made in 2015 on the license contracts signed in 2010 by Alfa S.r.l. with Delta S.p.a. confirms this vision. The modification, which reduces the revenues for Alfa S.r.l., was immediately accepted by the latter, even though in the last two years Alfa S.r.l. had very high losses. In view of these considerations resulting from a different contextualisation, expert B adopted very different data to carry out the estimate. And this took him to point out a brand value that is 15 times higher than that observed by expert A.

The empirical evidence shows that the contextualisation has a key role in the valuation of a company. Two investigations carried out in the same business context and formally correct in term of mathematical formula applied and discount rates found, may express final values that are far apart due to the different contextualisation adopted by the experts.

\section{Discussion and Future Research}

In Italian economy and elsewhere, small and medium-sized companies have a great relevance. The definition of the right ways to determine their value is a very crucial aspect.

The studies dealing with the valuation of a company, included in the general theory of value and value creation, pointed out the existence of different valuation models that may be used to estimate small and medium-sized businesses.

Regardless of the chosen valuation model, the quality of a valuation is deeply influenced by a series of factors such as the selected economic or financial flows, the timeframe of analysis and the discount rate adopted.

To determine all the records at the basis of the valuation in the right way, the "contextualisation" phase is crucial. This term refers to the general overview of all those elements that allow the proper definition of the company's background.

As explained in this paper, till now the academic literature, as well as the most important technical guides of valuation (International Valuation Standards - IVS - at an international level and Principi Italiani di Valutazione - PIV - as for Italy) have not provided a great relevance to contextualisation.

Instead, the present work focused on the importance of contextualisation in the valuation process. Infact, an undefined perspective in the observation of the business phenomenon may influence the quantification of the value of the company itself.

In other words, under the same conditions, a different contextualisation may change the quality and quantity of the records at the basis of the valuation process. This may be translated into an alteration of valuation inputs, due to the different interpretation of the valuator, who may not find any support in the regulatory instruments, except for some general concept. Consequently, all this impacts the entire estimate of the value significantly.

This was proved with the case study taken from the Italian context: two experts (expert A and expert B) were called to estimate the same business and both applied formally correct valuation methods. Nevertheless, even if the approaches were correct, the different contextualisation took them to express a final value that is completely different.

The rules determining the ways to contextualise are currently insufficient. After all, the issue was not dealt with thoroughly enough in literature.

Infact, returning to the case study, experts A and B carried out the same investigations, with the same theoretical bases, without giving instead the right emphasis to the contextualisation, achieving very different and incoherent results.

Thus, the investigation allows us to conclude that the valuation of a company, particularly for small and medium-sized businesses, still needs to be developed in the procedural law.

Infact, after explaining how contextualisation is important in the valuation processes of the companies, the academic literature is invited to take into consideration with greater attention this aspect of the company valuation.

It is therefore hoped that in the future there will be other studies that continue to develop this matter, by presenting case studies taken from social and economic fields, as well as different from the Italian one.

Moreover, it would be important that the future academic research defines the right procedures to approach the 
delicate and very important phase of contextualisation in the valuation of SMEs. This would allow not only to bridge the gap in the academic literature but also imperatively, it would help the valuators during their work and would increase the quality and reliability of the company valuation as a consequence.

\section{References}

Babin, B. J., \& James, K. W. (2010). A brief retrospective and introspective on value. European Business Review, 22(5), 471-478. https://doi.org/10.1108/09555341011068895

Bahri, M., St-Pierre, J., \& Sakka, O. (2011). Economic value added: a useful tool for SME performance management. International Journal of Productivity and Performance Management, 60(6), 603-621. https://doi.org/10.1108/17410401111150779

Barney, J. (1991). Firm resources and sustained competitive advantage. Journal of management, 17(1), 99-120. https://doi.org/10.1177/014920639101700108

Barry, B., Darden, W. R., \& Griffin, M. (1994). Work and/or fun: Measuring hedonic and utilitarian shopping value. Journal of consumer research, 20(4), 644-656. https://doi.org/10.1086/209376

Barth, M. E., Clement, M. B., Foster, G., \& Kasznik, R. (1998). Brand values and capital market valuation. Review of accounting studies, 3(1), 41-68. https://doi.org/10.1023/A:1009620132177

Batra, R., \& Ahtola, O. T. (1991). Measuring the hedonic and utilitarian sources of consumer attitudes. Marketing letters, 2(2), 159-170. https://doi.org/10.1007/BF00436035

Berkman, H., Bradbury, M. E., \& Ferguson, J. (1998). The magic of earnings in terminal value calculations. Journal of Financial Statement Analysis, 3, 27-33.

Bernard, V. L. (1994). Accounting-based valuation methods, determinant of market to book ratios, and implications for financial statements analysis. Working Paper of Michigan Business School. Retrived from https://deepblue.lib.umich.edu/bitstream/handle/2027.42/35398/b2014415.0001.001.txt?sequence=1\&isAll owed $=\mathrm{y}$

Bernard, V. L. (1995). The Feltham - Ohlson framework: implications for empiricists. Contemporary Accounting Research, 11(2), 733-747. http://dx.doi.org/10.1111/j.1911-3846.1995.tb00463.x

Bhojraj, S., \& Lee, C. (2002). Who Is My Peer? A valuation - based approach to the selection of comparable firms. Journal of Accounting Research, 40(2), 407-439. http://dx.doi.org/10.1111/1475-679X.00054

Bottenberg, K., Tuschke, A., \& Flickinger, M. (2017). Corporate Governance Between Shareholder and Stakeholder Orientation: Lessons From Germany. Journal of Management Inquiry, 26(2), 165-180. https://doi.org/10.1177/1056492616672942

Brady, M. K., Knight, G. A., Cronin, J. J., Tomas, G., Hult, M., \& Keillor, B. D. (2005). Removing the contextual lens: A multinational, multi-setting comparison of service evaluation models. Journal of Retailing, 81(3), 215-230. https://doi.org/10.1016/j.jretai.2005.07.005

Burns, R., \& Walker, J. (1991). Simultaneity of value and non-cash expenses in small business valuation. Journal of Small Business Management, 29(1), 10. Retrived from: https://search.proquest.com/openview/e92f220fc93f9d00b32eef20ac5bb82a/1?pq-origsite=gscholar\&cbl=4 9244

Cantillon, R. (1755). Essai sur la nature du commerce en general. Fletcher Gyles dans Holborn, Londra.

Cassia, L., Plate, A., \& Vismara, S. (2007). Equity valuation using DCF: A theoretical analysis of the long term hypotheses. Investment Management and Financial Innovations, 4(1), 91-108. Retrived from: https://businessperspectives.org/journals/investment-management-and-financial-innovations/issue-66/equity -valuation-using-dcf-a-theoretical-analysis-of-the-long-term-hypotheses

Charreaux, G., \& Desbrières, P. (2001). Corporate governance: stakeholder value versus shareholder value. Journal of Management and Governance, 5(2), 107-128. https://doi.org/10.1023/A:1013060105433

Cornell, B., \& Gerger, R. (2017). A Note on Estimating Constant Growth Terminal Values with Inflation. Retrived from: https://ssrn.com/abstract $=2973345$

Courteau, L., Gray, P., Kao, J. L., O'Keefe, T., \& Richardson, G. D. (2007). Constructing intrinsic value estimates of equity using IBES and value line forecasts of fundamentals. Retrived from: http://dx.doi.org/10.2139/ssrn.993847

Courteau, L., Kao, J. L., \& Richardson, G. D. (2001). Equity valuation employing the ideal versus ad hoc 
terminal value expressions. Contemporary accounting research, 18(4), 625-661. http://dx.doi.org/10.1506/77TK-1N3Q-82QU-UATR

Damodaran, A. (2016). Damodaran on valuation: security analysis for investment and corporate finance (Vol. 324). John Wiley \& Sons.

Donna, G. (1999). La creazione di valore nella gestione dell'impresa. Carocci, Roma

Ehrbar, A., \& Stewart, G. B. (1999). The EVA revolution. Journal of Applied Corporate Finance, 12(2), 18-31. http://dx.doi.org/10.1111/j.1745-6622.1999.tb00005.x

Eisenhardt, K. M. (1989). Building theories from case study research. Academy of management review, 14(4), 532-550. http://dx.doi.org/10.5465/AMR.1989.4308385

Eisenhardt, K. M., \& Graebner, M. E. (2007). Theory building from cases: Opportunities and challenges. Academy of management journal, 50(1), 25-32. http://dx.doi.org/10.5465/AMJ.2007.24160888

Ellwood, S., \& Greenwood, M. (2016). Accounting for heritage assets: Does measuring economic value 'kill the cat'?. Critical Perspectives on Accounting, 38, 1-13. https://doi.org/10.1016/j.cpa.2015.05.009

Fatemi, A., Fooladi, I., \& Tehranian, H. (2015). Valuation effects of corporate social responsibility. Journal of Banking \& Finance, 59, 182-192. https://doi.org/10.1016/j.jbankfin.2015.04.028

Fernández, P. (2007a). Valuing companies by cash flow discounting: ten methods and nine theories. Managerial Finance, 33(11), 853-876. https://doi.org/10.1108/03074350710823827

Fernandez, P. (2007b). A more realistic valuation: Adjusted present value and WACC with constant book leverage ratio. Journal of Applied Finance, 17(2), 13-20. Retrived from: search.ebscohost.com/login.aspx?direct=true $\& \mathrm{db}=$ buh\&AN=32604417\&site=ehost-live \&scope $=$ site.

Francis, J., Olsson, P., \& Oswald, D. R. (2000). Comparing the accuracy and explainability of dividend, free cash flow, and abnormal earnings equity value estimates (Digest Summary). Journal of accounting research, 38(1), 45-70. http://dx.doi.org/10.2307/2672922

Freeman, R. E. (1984). Strategic management: A stakeholder approach. Boston, MA: Pitman.

Freeman, R. E., Harrison, J. S., \& Wicks, A. C. (2007). Managing for stakeholders: Survival, reputation, and success. Yale University Press.

Freeman, R. E., Wicks, A. C., \& Parmar, B. (2004). Stakeholder theory and "the corporate objective revisited". Organization science, 15(3), 364-369. https://doi.org/10.1287/orsc.1040.0066

Friedman, M. (1970). The Social Responsibility of Business is to make profit. New York Times Magazine, 13.

Golz Jr, W. C. (1986). Valuation and LBOs. Buyouts and Acquisitions, 4, 41-44.

Goodman, E., Bamford, J., \& Saynor, P. (Eds.). (2016). Small firms and industrial districts in Italy. Routledge.

Gribbin, J. (1984). In search of Schrödinger's cat. London: Black Swan Books, Random House.

Gribbin, J. (1995). Schrödinger's kittens — and the search for reality. London: Phoenix.

Guatri, L. (1991). La teoria di creazione del valore: una via europea. Egea, Milano

Gummerus, J. (2013). Value creation processes and value outcomes in marketing theory: strangers or siblings? Marketing Theory, 13(1), 19-46. https://doi.org/10.1177/1470593112467267

Harrison, J. S., \& Wicks, A. C. (2013). Stakeholder theory, value, and firm performance. Business ethics quarterly, 23(1), 97-124. https://doi.org/10.5840/beq20132314

Heinonen, K., Strandvik, T., Mickelsson, K. J., Edvardsson, B., Sundström, E., \& Andersson, P. (2009). Rethinking service companies' business logic: do we need a customer-dominant logic as a guideline? Working paper. Retrived from: http://urn.fi/URN:ISBN:978-952-232-072-8

Hirschman, E. C., \& Holbrook, M. B. (1982). Hedonic consumption: emerging concepts, methods and propositions. The Journal of Marketing, 92-101. http://doi.org/10.2307/1251707

Hoyer, W. D., Chandy, R., Dorotic, M., Krafft, M., \& Singh, S. S. (2010). Consumer cocreation in new product development. Journal of service research, 13(3), 283-296. https://doi.org/10.1177/1094670510375604

Hromei, A. S., \& Voinea, M. M. (2014). Valuation and creative accounting. Cross-Cultural Management Journal, (5), 197-208. Retrived from: https://doaj.org/article/e6923e420e654da9b5a0cb62b508b209

International Valuation Standards Council (IVSC). (2017). International Valuation Standards. Norwich. 
ISTAT. (2015). Anno 2013: Struttura e competitività del sistema delle imprese industriali e dei servizi. Retrived from: https://www.istat.it/it/files/2015/12/Struttura-e-competitivit\%C3\%A0_2013.pdf?title=Struttura+e+competiti vit $\%$ C3\%A0+delle+imprese++-+09\%2Fdic\%2F2015+-+Testo+integrale+e+nota+metodologica.pdf

Javons, W. S. (1871). The theory of Political Economy. London.

Jennergren, L. P. (2008). Continuing value in firm valuation by the discounted cash flow model. European journal of operational research, 185(3), 1548-1563. https://doi.org/10.1016/j.ejor.2006.08.012

Jensen, M. C. (2001). Value maximization, stakeholder theory, and the corporate objective function. Journal of applied corporate finance, 14(3), 8-21. http://dx.doi.org/10.1111/j.1745-6622.2001.tb00434.x

Jensen, M. C. (2002). Value maximization, stakeholder theory, and the corporate objective function. Business ethics quarterly, 12(2), 235-256. https://doi-org.ezproxy.unibg.it/10.2307/3857812

Kaplan, S. N., \& Ruback, R. S. (1995). The valuation of cash flow forecasts: An empirical analysis. The Journal of Finance, 50(4), 1059-1093. http://dx.doi.org/10.1111/j.1540-6261.1995.tb04050.x

Keynes, J.M. (1936). General Theory of Employment, Interest and Money. Reprint Atlantic Publishers \& Dist.

Lippitt, J. W., \& Mastracchio Jr, N. J. (1993). Valuing small businesses: Discounted cash flow, earnings capitalization, and the cost of replacing capital assets. Journal of small business management, 31(3), 52. Retrived from: https://search.proquest.com/openview/c9dbf21e2aaa2fcbe2eb629f518fb363/1?pq-origsite=gscholar\&cbl=4 9244

Lovata, L. M., \& Costigan, M. L. (2002). Empirical analysis of adopters of economic value added. Management Accounting Research, 13(2), 215-228. https://doi.org/10.1006/mare.2002.0181

Malthus, T. R. (1823). The Measure of Value Stated and Illustrated: with an Application of it to the alterations in the value of English currency since 1790. J. Murray, London.

Marshall, A. (1890). Principles of economy, Great minds series. Cosimo Classics, New York.

Marx, K., \& Engels, F. (1867). Das capital. Hamburg.

McCarthy, E. (1999). Pricing IPOs: Science or science fiction? Journal of Accountancy, 188(3), 51. Retrived from:

https://search.proquest.com/openview/b256f60dd332253251192940d9206996/1?pq-origsite=gscholar\&cbl= 41065

Menger, C. (1871). Grundsätze der volkswirtschaftslehre. English translation, (1950), Principles of economics, Glencoe, Illinois.

Niresh, A. J., \& Alfred, M. (2014). The association between economic value added, market value added and leverage. International Journal of Business and Management, 9(10), 126. http://dx.doi.org/10.5539/ijbm.v9n10p126

OECD. (2017). Small, Medium, Strong. Trends in SME Performance and Business Conditions. OECD Publishing, Paris.

Organismo Italiano di Valutazione (OIV). (2015). Principi Italiani di Valutazione. Egea.

Pascual, L. B., \& Jiménez, L. G. (2009). Discounted cash-flow model: Terminal value computation alternatives. XVII Foro de Finanzas 2009.

Patterson, P. G., \& Spreng, R. A. (1997). Modelling the relationship between perceived value, satisfaction and repurchase intentions in a business-to-business, services context: an empirical examination. International Journal of service Industry management, 8(5), 414-434. https://doi.org/10.1108/09564239710189835

Payne, A. F., Storbacka, K., \& Frow, P. (2008). Managing the co-creation of value. Journal of the academy of marketing science, 36(1), 83-96. https://doi.org/10.1007/s11747-007-0070-0

Payne, A., Storbacka, K., Frow, P., \& Knox, S. (2009). Co-creating brands: Diagnosing and designing the relationship experience. Journal of Business Research, 62(3), 379-389. https://doi.org/10.1016/j.jbusres.2008.05.013

Penman, S. (2016). Valuation: The state of the art. Schmalenbach Business Review, 17(1), 3-23. https://doi.org/10.1007/s41464-016-0002-y 
Penman, S. H. (1998). A synthesis of equity valuation techniques and the terminal value calculation for the dividend discount model. Review of Accounting Studies, 2(4), 303-323. https://doi.org/10.1023/A:1023688704798

Penman, S. H., \& Sougiannis, T. (1998). A comparison of dividend, cash flow, and earnings approaches to equity $\begin{array}{lllll}\text { valuation. Contemporary accounting } & \text { 343-383. }\end{array}$ http://dx.doi.org/10.1111/j.1911-3846.1998.tb00564.x

Perrini, F., Chiaccheri, C., \& Perrone, V. (2008). I-Valuation. Intangibili, competitività e valutazione d'impresa. Egea, Milano.

Petty, W. (1662). A treatise of taxes and contributions. London.

Porter, M. E. (1985). Competitive Advantage. New York, NY: The Free Press.

Prahalad, C. K., \& Ramaswamy, V. (2004). Co-creating unique value with customers. Strategy \& leadership, 32(3), 4-9. https://doi.org/10.1108/10878570410699249

Ranjan, K. R., \& Read, S. (2016). Value co-creation: concept and measurement. Journal of the Academy of Marketing Science, 44(3), 290-315. https://doi.org/10.1007/s11747-014-0397-2

Ravald, A., \& Grönroos, C. (1996). The value concept and relationship marketing. European journal of marketing, 30(2), 19-30. https://doi.org/10.1108/03090569610106626

Reis, P. M. N., \& Augusto, M. G. (2014). Determinants Of Firm Terminal Value: The Perspective Of North American And European Financial Analysts. The International Business \& Economics Research Journal (Online), 13(4), 793. http://dx.doi.org/10.19030/iber.v13i4.8687

Reis, P., \& Augusto, M. (2013). The terminal value (TV) performing in firm valuation: The gap of literature and research agenda. Journal of Modern Accounting and Auditing, 9(12), 1622-1636. Retrived from: http://hdl.handle.net/10400.19/3621

Ricardo, D. (1817). The Principles of political economy and taxation. John Murray, London.

Roggeveen, A. L., Tsiros, M., \& Grewal, D. (2012). Understanding the co-creation effect: when does collaborating with customers provide a lift to service recovery? Journal of the Academy of Marketing Science, 40(6), 771-790. https://doi.org/10.1007/s11747-011-0274-1

Sheth, J. N., Newman, B. I., \& Gross, B. L. (1991a). Consumption values and market choices: Theory and applications (pp. 16-74). Cincinnati: South-Western Publishing Company.

Sheth, J. N., Newman, B. I., \& Gross, B. L. (1991b). Why we buy what we buy: A theory of consumption values. Journal of business research, 22(2), 159-170. https://doi.org/10.1016/0148-2963(91)90050-8

Sichigea, D. F., \& Berceanu, D. (2006). Determination Of Company Value By The Approach Based On Assets. Journal of Applied Economic Sciences (JAES), (1), 9-13. Retrived from: http://www.jaes.reprograph.ro/articles/Berceanu.pdf

Smith, A. (1776). An inquiry into the nature and causes of the wealth of nations. London.

Sraffa, P. (1960). Production of commodities by means of commodities. Vora \& Co. Publishers LTD.

Stabell, C. B., \& Fjeldstad, Ø. D. (1998). Configuring value for competitive advantage: on chains, shops, and $\begin{array}{llll}\text { networks. } & \text { Strategic } & \text { Management } & \text { Journal, }\end{array}$ http://dx.doi.org/10.1002/(SICI)1097-0266(199805)19:5<413::AID-SMJ946>3.0.CO;2-C

Stern, J. M., Stewart, G. B., \& Chew, D. H. (1996). Eva®*: An integrated financial management system. European Financial Management, 2(2), 223-245. http://dx.doi.org/10.1111/j.1468-036X.1996.tb00039.x

Steward, G. B. (1991). The quest for value: a guide for senior managers. New York.

Sweeney, J. C., \& Soutar, G. N. (2001). Consumer perceived value: The development of a multiple item scale. Journal of retailing, 77(2), 203-220. https://doi.org/10.1016/S0022-4359(01)00041-0

Thompson, C. J., Locander, W. B., \& Pollio, H. R. (1989). Putting consumer experience back into consumer research: The philosophy and method of existential-phenomenology. Journal of consumer research, 16(2), 133-146. https://doi.org/10.1086/209203

Torrens, R. (1815). An essay on the production of wealth. London.

Treacy, M., \& Wiersema, F. (1993). Customer intimacy and other value disciplines. Harvard business review, 
71(1), 84-93. Retrived from: http://itirelengmicro.co.za/Customer\%20Intimacy.pdf

Ulaga, W. (2003). Capturing value creation in business relationships: A customer perspective. Industrial marketing management, 32(8), 677-693. https://doi.org/10.1016/j.indmarman.2003.06.008

Unione Europeenne des Experts Comptables Economiques et Financiers. (1961). Récommandations sur les procédures à suivre par les experts comptables en maitre d'enterprise.

Vargo, S. L., \& Lusch, R. F. (2008). Service-dominant logic: continuing the evolution. Journal of the Academy of marketing Science, 36(1), 1-10. https://doi.org/10.1007/s11747-007-0069-6

Walras, L. (1900). Éléments d'économie politique pure. Lausanne.

Wernerfelt, B. (1984). A resource - based view of the firm. Strategic management journal, 5(2), 171-180. http://dx.doi.org/10.1002/smj.4250050207

West, T. L., \& Jones, J. D. (Eds.). (1992). Handbook of business valuation. Wiley.

Wikström, S. (1996). Value creation by company - consumer interaction. Journal of Marketing Management, 12(5), 359-374. http://dx.doi.org/10.1080/0267257X.1996.9964422

Woodall, T. (2003). Conceptualising'value for the customer': An attributional, structural and dispositional analysis. Academy of marketing science review, 2003, 1. Retrived from: https://search.proquest.com/openview/21 f984d1dc92a52d0c3ef67409f89ea8/1?pqorigsite=gscholar\&cbl=25 818

Woodcock, J. (1993). Buying or Selling a Business? Don't Be Ripped Off!. Business Quarterly, 57, 41-41.

Woodruff, R. B. (1997). Customer value: the next source for competitive advantage. Journal of the academy of marketing science, 25(2), 139-153. https://doi.org/10.1007/BF02894350

Yin, R. K. (1994). Case study research: Design and methods. Sage publications.

Young, D. (1997). Economic value added: A primer for European managers. European Management Journal, 15(4), 335-343. https://doi.org/10.1016/S0263-2373(97)00014-5

\section{Notes}

Note 1. In this case "small and medium-sized business" means companies with less than 250 employees.

Note 2. PIV are based on IVS. Nevertheless, the firsts are designed to have principles that reflect in the best way the culture, operational practice, economic, regulatory and legal Italian framework. Thus, as a matter of principle, an expert that is called to carry out a valuation in the Italian context should adhere to the PIV as well as following the IVS.

Note 3. The 'strength' of a brand was measured by considering the factors identified in the 'Interbrand' valuation method. These factors are: leadership, market, stability, trends, protection, support, internationality. For further information: Barth et al. (1998).

Note 4. According to the Italian Gaap (principle no. 25), the credits for prepaid activities should be budgeted only if the company is likely to have taxable incomes to use these fiscal advantages in the future. In the last two years $(2014,2015)$, Alfa S.r.l. reported significant losses.

\section{Copyrights}

Copyright for this article is retained by the author(s), with first publication rights granted to the journal.

This is an open-access article distributed under the terms and conditions of the Creative Commons Attribution license (http://creativecommons.org/licenses/by/4.0/). 